\title{
Waste Fashion Product Design
}

\author{
Asst. Prof. Worasuda Khwansuwan ${ }^{1}$ and Asst. Prof. Satinee Wattanakit ${ }^{2}$ \\ ${ }^{1}$ Faculty of Architecture, Art and Design Department Rajamangala University of Technology Srivijaya, \\ Songkhla, Thailand \\ ${ }^{2}$ Faculty of Architecture, Architecture Department Rajamangala University of Technology Srivijaya, Songkhla, \\ Thailand \\ *Corresponding author
}

\begin{abstract}
Nowadays, the world is facing a severe environmental crisis. Due to the development of technology and population growth, a large quantity of consumption goods such as food, clothes and dwelling is produced to serve people's demand. As a result, humans are continually creating a huge production of waste. Industries and households generate an excessive amount of waste or garbage which is a major threat to the environment. If we do not address this issue seriously, we are doomed for environmental disaster. Regarding to this concern, one solution of waste disposal that helps to minimize the excessive residual waste is the use of 3R (Reuse, Reduce and Recycle). This process involves recycling and transforming waste materials into fashionable value-added items. Not only does it reduce the amount of waste pollution, but it also adds the value of waste and creates income for the people.

This research project adopted the principles of arts and design to transform waste materials into value-added products such as home decoration items and fashion products. The process involved using the elements of design such as size, shape and color which resulted in beautifully designed and new products from waste materials. Moreover, the body of knowledge gained from this research contributed to the community. The people in the target community have been taught to make their own products from waste materials. Through the recycling of waste, they could create their new products while reducing the impact of waste on the environment. This research is, therefore, helps to promote job opportunity, sustainability and practical solutions for reducing waste.
\end{abstract}

Keywords: waste; fashion product design

\section{Introduction}

Nowadays, the world is facing a severe environmental crisis. Due to the development of technology and population growth, a large quantity of consumption goods such as food, clothes and dwelling is produced to serve people's demand. As a result, humans are continually creating a huge production of waste. Industries and households generate an excessive amount of waste or garbage, which is a major threat to the environment.

In response to such problem, there have been several attempts to minimize the excessive residual waste and garbage. One promising alternative is the use of 3R (Reuse, Reduce and Recycle). The process involves recycling and transforming waste materials into fashionable 
value-added items such as home decoration items and fashion products. In doing so, it can reduce the amount of waste pollution and, at the same time, add the value of waste and create income for the people in Khao Rupchang community, where the research was undertaken.

The researchers selected Khao Rupchang community as a research site because of two main reasons. First, the community adopted waste management policy called 'Clean Province 2020', which is closely relevant to the purpose of this study. Such policy adopted academic principles to help in the procedure of waste disposal. This included encouraging people to have more realization and understanding of how to manage garbage in their household. These practices help the community to maintain a clean and hygienic living environment for the people (National News Bureau of Thailand, 2562). Second, as shown in Figure 1 below, it is evidenced that many places in the community tended to create a great amount of waste. The reasons mentioned above, therefore, suggest that Khao Rupchang community has potential for the research to be undertaken.

Table 1. Information on waste production in the community

\begin{tabular}{|c|c|c|c|c|c|c|c|}
\hline No & Area/Province & $\begin{array}{c}\text { amount of } \\
\text { waste } \\
\text { generated } \\
\text { (Ton/day) }\end{array}$ & $\begin{array}{c}\text { Number of } \\
\text { local } \\
\text { government } \\
\text { organizations } \\
\text { serving }\end{array}$ & $\begin{array}{c}\text { The amount of } \\
\text { waste generated } \\
\text { in the local } \\
\text { government } \\
\text { organization } \\
\text { service area } \\
\text { (ton / day) }\end{array}$ & $\begin{array}{c}\text { The } \\
\text { amount of } \\
\text { waste } \\
\text { collected } \\
\text { for } \\
\text { disposal } \\
\text { (ton / day) }\end{array}$ & $\begin{array}{c}\text { The } \\
\text { amount } \\
\text { of waste } \\
\text { has been } \\
\text { utilized } \\
\text { (Ton / } \\
\text { day) }\end{array}$ & $\begin{array}{c}\text { The } \\
\text { amount } \\
\text { of waste } \\
\text { is not } \\
\text { served } \\
\text { (ton / } \\
\text { day) }\end{array}$ \\
\hline 1 & $\begin{array}{c}\text { Khao } \\
\text { Rupchang } \\
\text { community }\end{array}$ & 46.67 & 1 & 46.67 & 38.79 & 7.88 & - \\
\hline
\end{tabular}

Source: Khao Rup Chang Subdistrict Municipality
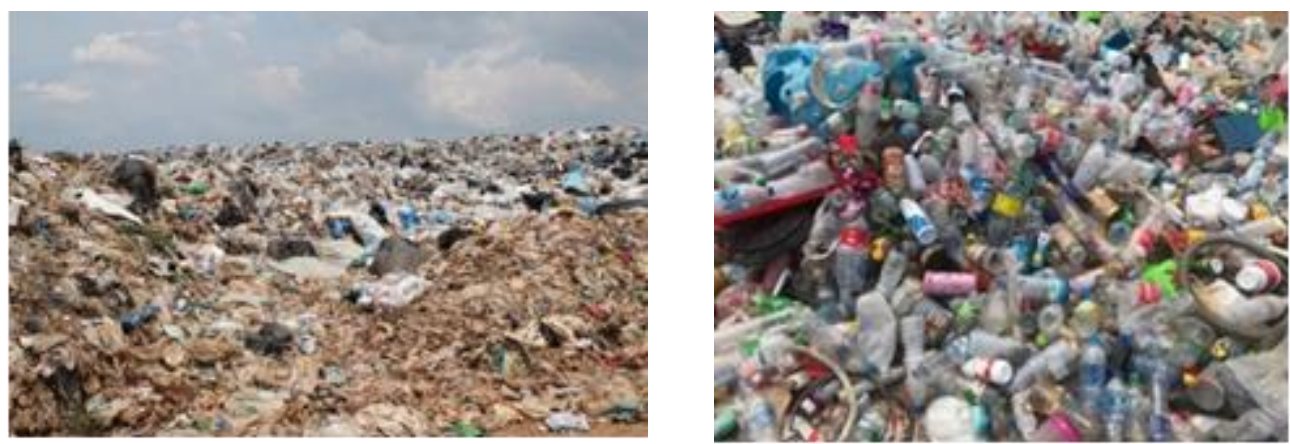

Figure 1. Waste production in the community Khaoroopchang Municipality

Source: Researcher team

\section{The Objectives}

The objectives of this study are:

1) To design and create new products that are made from waste materials.

2) To provide added value to waste materials by transforming them into fashionable items such as home decoration items and fashion products 
3) To create income for the target community by making and selling the products from waste material products.

\section{Expected results}

The study has expected results as follows:

\subsection{Environmental benefits}

Though the use of 3R, waste materials were recycled and transformed into fashionable value-added items. It reduced the impact of waste on the environment and yielded less pollution.

\subsection{Social benefits}

Participants and people in the community theoretically and practically learned how to create waste material products. They developed a good understanding of the elements of design and were able to design their own products from waste materials in the future.

\subsection{Economic benefits}

People had more income from making and selling waste material products, which can be sold in the national and international market. As a result, there were more job opportunities in the community and people had better living conditions.

\section{Methodology}

The methods and procedures adopted to carry out this study were as follows:

\subsection{Site studying}

The researchers studied the literature and collected relevant information in order to select target community. Then, after specifying the target community (Khao Rupchang community), the research team conducted a site surveying at Khao Rupchang community to collect waste materials and analyse their properties. This information was useful for the step of concept design as will be discussed in the following section. The Table 2 below shows types and amount of waste found at the research site.

Table 2. Types and amount of waste

\begin{tabular}{cll}
\hline No & Types & Amount ()$\%($ \\
\hline 1 & Organic waste & 60 \\
\hline 2 & Plastic & 25 \\
\hline 3 & Glass & 5 \\
\hline 4 & Dried leaves/ twigs & 4 \\
\hline 5 & Paper & 2 \\
\hline 6 & Foam/construction debris & 2 \\
\hline 7 & Metal & 1 \\
\hline
\end{tabular}




\subsection{Designing process}

The researchers constructed a conceptual framework to set scope and direction for the design process. This study employed the concept of nature and geometric shapes in the design. Different aspects were taken into account. They were, for example, the properties of waste materials, function, appropriateness, beauty and utility. The design processes are described below.

\subsubsection{Analyzing the properties of the selected waste materials}

According to the table below, it was found that physical shape of a plastic bottle can be modified by cutting, trimming and heating without using chemical processes. This modification process accorded with the upcycle process. Upcycling involves turning waste materials into a new product which is more valuable and practical. More importantly, the new product and its production process are environmental friendly. In other words, the process for upcycling involves the design that does not use energy, other resources or chemical process that is harmful to the environment (Jakkrit Siririn, 2562).

Table 3. Properties of plastic bottle

\begin{tabular}{lll}
\hline Types of material & Property & Application \\
\hline Plastic bottle & Translucent, soft, flexible and tough & Not through chemical \\
& Having acid and alkali resistance & processes \\
Low liquid absorption & \\
Low barrier to most gases and fats & Modify physical shape \\
Good for heat sealing & \\
Appropriate for any temperature & \\
Safe for food and drug container & \\
\hline
\end{tabular}

Source: Khao Rup Chang Subdistrict Municipality

- Constructing design concept that was compatible with the properties of the selected waste materials. The process started from sketching $2 \mathrm{D}$ shapes and later turned them into a 3D design.

- Analyzing, revising and improving ideas until settling upon the final design.

\subsection{Making a prototype}

This stage involved making a prototype using selected waste materials as indicated above. Then, the prototype was tested for its usability. Feedback were sought from three supervisors from different fields of expertise namely, 1) architecture/ interior architecture, 2) product/fashion design, and 3) marketing. The prototype of each product is illustrated below.

This research uses plastic waste materials such as plastic color bottoms and design takes inspiration from nature shapes. Using materials to create shapes designed by art and design theory and principles. Prototype products that are both beautiful and functional in parallel can be sold in the market and online. 


\subsubsection{Fashion products}

\section{Accessories}

The process of creating a flower accessories

The design of table lamp is inspired by the jasmine flower. With its graceful shape, the designer assessed that it can be assembled into a piece using artistic principles of art; line, grace, and unity.

- Shorten the shape of jasmine flower to create the shape used to create the product.

- Take plastic bottles color and cut them into the designed jasmine flower shape.

- Assembling plastic jasmine flower shape, stacking plastic bottles as an accessories set
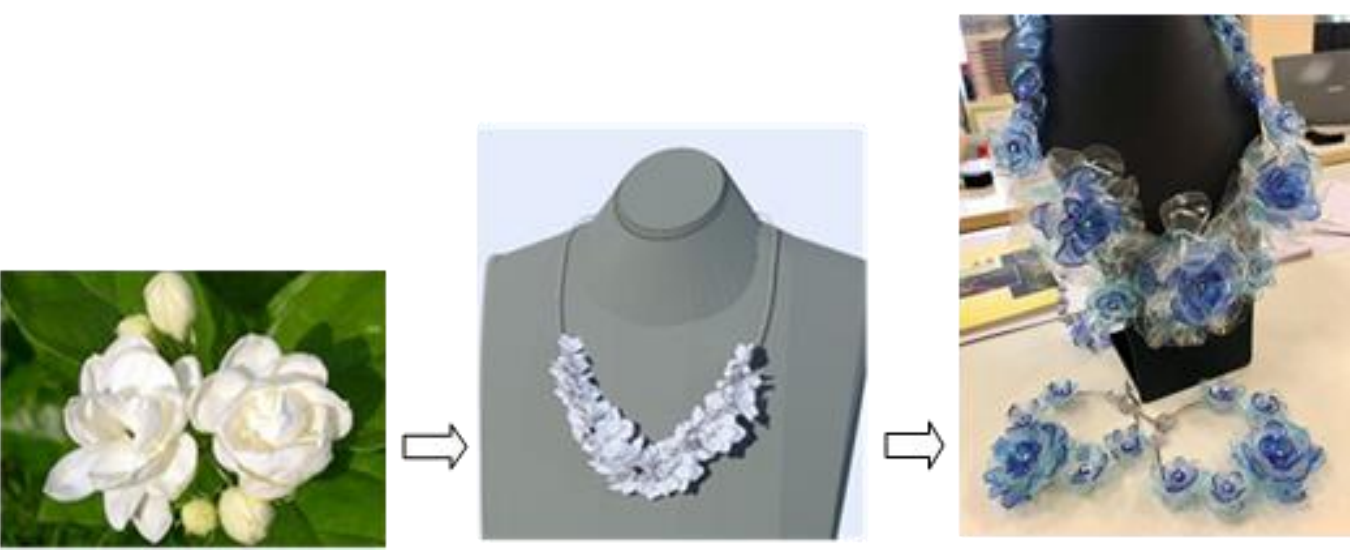

Figure 2. Design concept

Source: Khwansuwan and Researcher team

\section{Evaluating product satisfaction}

The research team used a questionnaire to investigate opinions and product satisfaction from 200 population. They were classified into two groups. One group consisted of those who worked in design industry and another group was general people. The result were

The percentage of people in the community showed interest in utilizing the waste material products was 61.40 and 38.60 percentage uninterested in utilizing of waste material products. In addition, they are interested in purchasing products from waste materials about 73.70 percent and 26.30 percent uninterested in buying. Shows in Figure 3. 

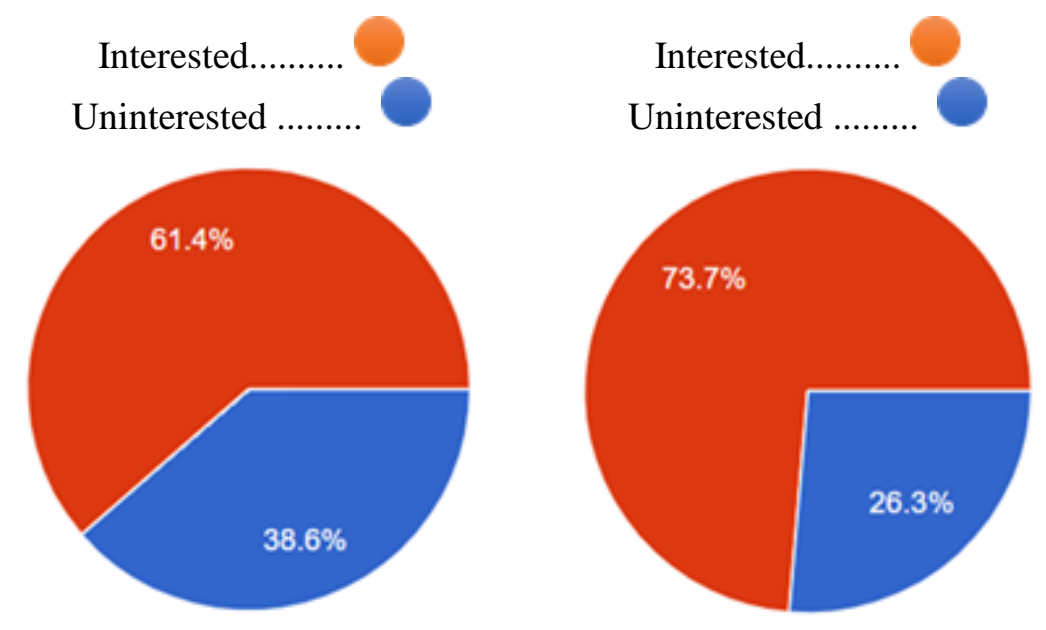

Figure 3. Satisfaction percentage

Source: Researcher team

\section{Transferring knowledge}

\subsection{Academic community}

The researchers disseminated knowledge gained from the research to the public by presenting the products in many academic work and presentation. Products display showed as seen in Figure 4 and as participants visiting the display seen in Figure 5.
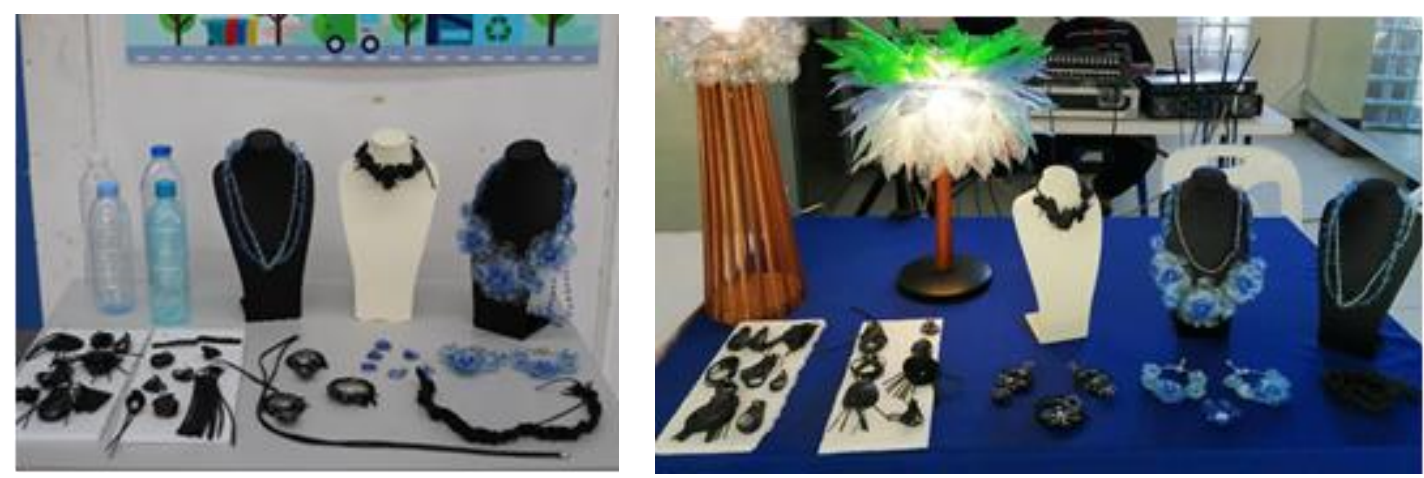

Figure 4. Products display

Source: Researcher team 

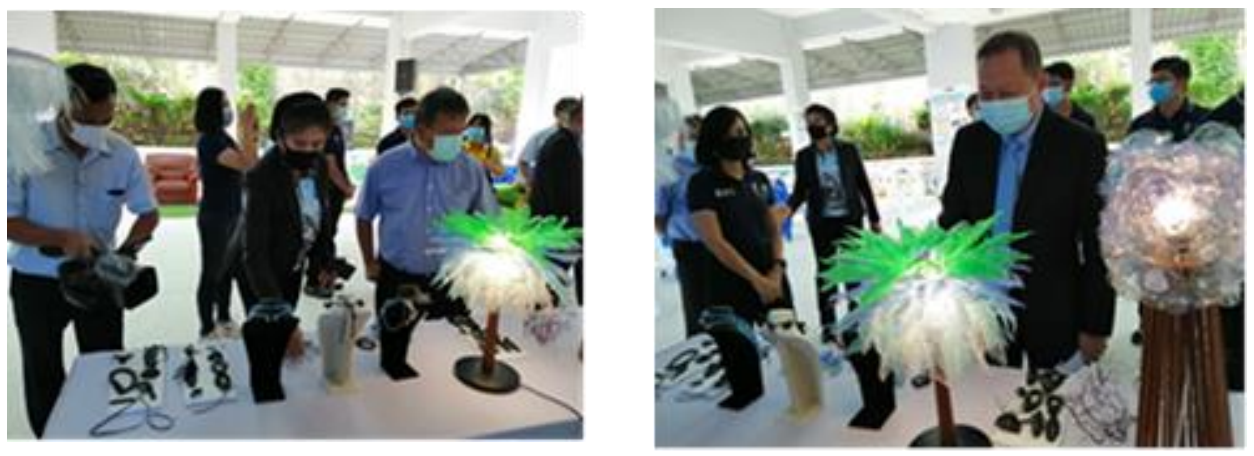

Figure 5. Participants visiting the display

Source: Researcher team

\subsection{Khao Rupchang community}

The research team sharing knowledge from the research to people in Khao Rupchang community. The participants were taught and trained to make the products. Then they started working by themselves under close supervision of the researchers as seen in Figures 6 and 7 .
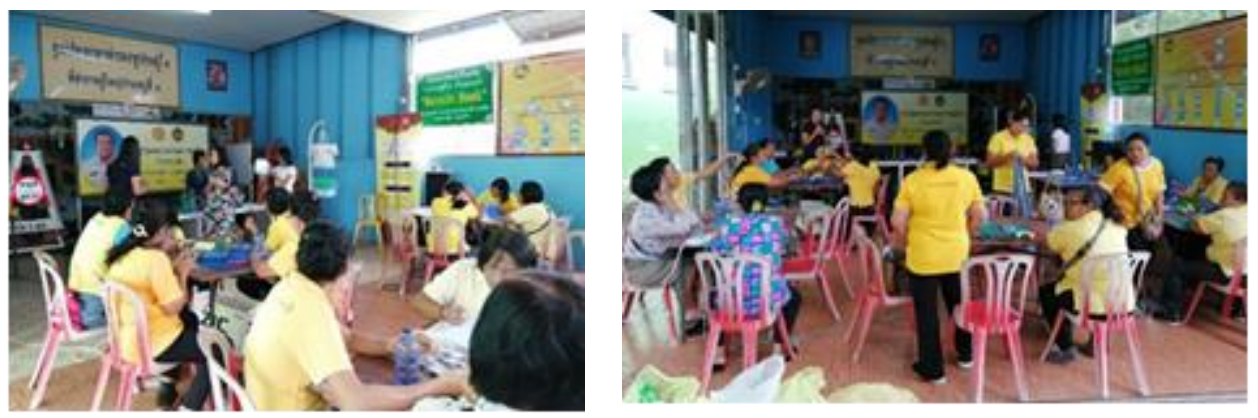

Figure 6. Researchers explaining the production process

Source: Researcher team
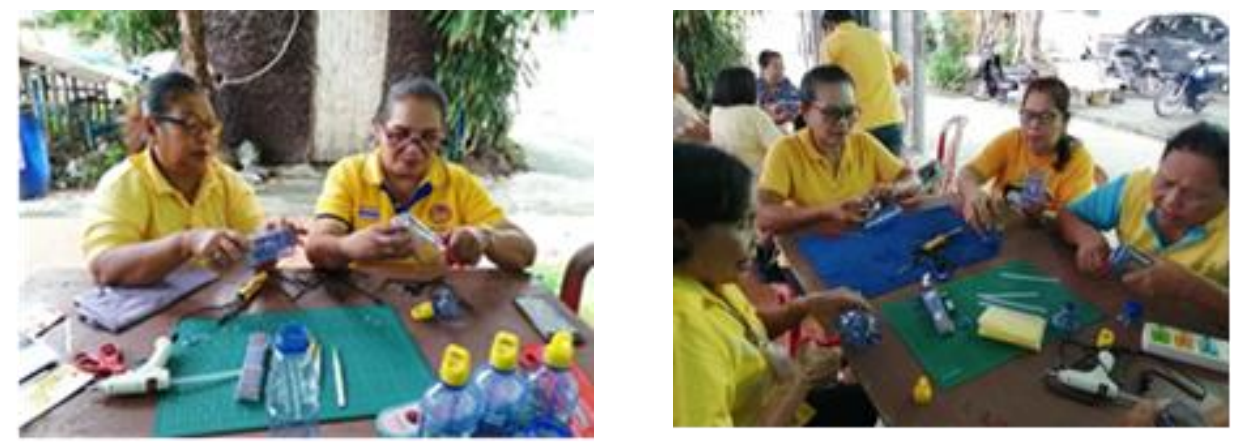

Figure 7. Participants working on the products.

Source: Researcher team

\subsubsection{Selling the products}

Waste produce made from people in Khao Rupchang community was variety from their ideas. Which they can create by themselves. The product had more interested to sold and 
useful. Especially, People in communities had more income from sell waste products. The finished products as illustrated in Figure 8 were sold online or directly to the customers.
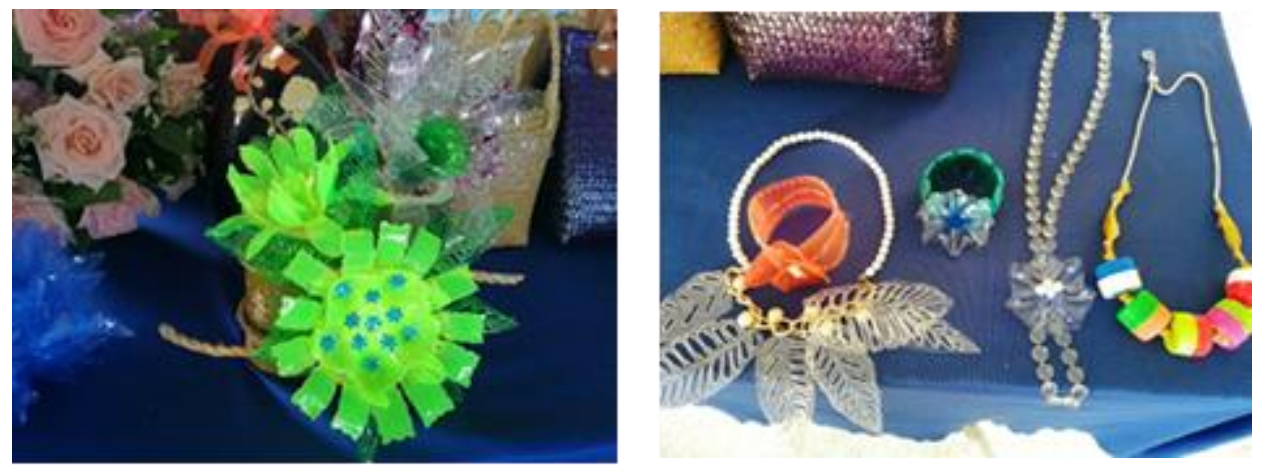

Figure 8. Finish products by people in Khao Rupchang community.

Source: Researcher team

\section{Conclusion}

In conclusion, the research is, helps to promote job opportunity, sustainability and practical solutions for reducing waste in environment. After research team sharing knowledge in Khao Rupchang community. The participants were taught and trained to make the products. Then they started working by themselves and contributing to reducing waste and generating income by selling products from waste materials. According to interview Mr.Thanin Ausuwan Head of Public Health Administration in Khao Rup Chang Sub-district Municipality as he said the research is the way to reduce waste in Khao Rupchang community.

Moreover, the research allowing villagers to create products from waste materials and selling products to generate income. By interview people in Khao Rupchang community Mrs.Juthamat Keawaree who is the reader of village no.6 in Khao Rupchang community explained about can working waste product by her selves and create product and selling. She has more income to her family and live life. In the future, researcher would like to sharing knowledge of methods and processes about waste material produce design to other villages for the community. Hopefully, the communities can create waste fashion produces to earn more income to have a sustainable livelihood and reduce the amount of waste in the community.

\section{References}

Amnuay Wattanakornsiri. (2555). Environmental Science Program, Faculty of Science and Technology, Surindra Rajabhat University. Surin.

Kanala Kobvittaya. (2560). Waste management : A case study of Mueng Narathiwat Municipality. Ramkhamhaeng Journal of Public Administration. Bangkok 
Natthikan Pinjirai. (2557). Industrial ProductDesign: Key Concepts and Principles. Kamphaengphet Rajabhat University. Kamphaengphet.

Peeraya Vajarodaya. (2556). Local authority's solid waste management: a case study of Muangklang municipality, Rayong province. Graduate School of Social and Environmental Development. National Institute of Development Administration. Bangkok.

Piyaporn Kumyingyong. (2558). Maximizing the Value of Material scraps and Turning into Eco Products. Bangkok University. Bangkok.

Somsak Pomjunk. (2561). The Reduction of Global Warming under the Recycling Projec by Creative Art through the Participation of Communities in Muang District, Chiang Mai. Chiang Mai Rajabhat University. Chiang Mai.

Suwit Sadsunk. (2552). The design of the women's party dress was based on the theory of aesthetics, Aristotle's imitation of nature and inspiration from the anemone. Suan Sunandha Rajabhat University. Bangkok.

Takorn TavornchotIvong (2561). A Development of thai materials waste to creative craft. Silpakorn University. Decorative Arts. Nakornprathom.

Thitirat Manipharak. (2563). Waste management in accordance with $3 R$ principles in the Eastern Bangkok area. Rattana Bundit University. Bangkok.

Witchaya Khotarathititham. (2558). Decorative lamp design from waste cotton by fabric manipulation technique. Silapakorn University .Bangkok.

Yanin Mathurasa. (2556). Natural fiber illuminant souvenir design for tourist. Silapakorn University. Nakornprathom. 